\title{
Prevalence of Clinical Mastitis and the Suitability of Gamma Function in Predicting Milk Yield of Mastitic and Non-Mastitic Friesian x Bunaji Dairy Cows in Zaria, Nigeria
}

\author{
Moru, Nana Hauwa ${ }^{1}$; Umoh, J U²; Maikai, B V²; Barje, P P ${ }^{1}$; Adeyinka, I. A ${ }^{1}$. \\ ${ }^{I}$ National Animal Production Research Institute, Ahmadu Bello University P.M.B 1096, Shika-Zaria, Nigeria. \\ ${ }^{2}$ Veterinary Public Health and Preventive Medicine, Faculty of Veterinary Medicine, Ahmadu Bello University, \\ Zaria, Nigeria.
}

\begin{abstract}
Bovine mastitis has been known to cause considerable losses in the dairy industry. Knowledge of the occurrence and incidence of clinical mastitis in dairy cows is of great importance for monitoring the health status of the mammary glands, also in institution and implementation of control programs for the disease. The aim of this study was to determine the occurrence of clinical mastitis in Friesian X Bunaji crossbred dairy cows in a Research farm in Zaria, Nigeria. This was a cross-sectional study which involved the use of passive data (lactation records) generated from 2000 to 2015 in the Dairy Research Programme of a National Animal Production Research Institute, Shika-Zaria. The prevalence of clinical mastitis was determined and the lactation curve for the Friesian x Bunaji cows was designed and analyzed using the Gamma Function by Wood(1967). The prevalence of clinical mastitis was found to increase with increasing parity number $(0.30,0.32$ and 0.43 for parity 1, 2 and 3 respectively). High prevalence of clinical mastitis occurred in early lactation period of parity 1 cows, but highest prevalence was recorded during the late lactation period in parities 2 and 3 cows.
\end{abstract}

Keywords: Clinical mastitis, Friesian x Bunaji cows, lactation curve.

\section{Introduction}

Bovine mastitis(which could be clinical or subclinical) causes health disorders in the mammary gland and could result in significant losses in milk yield as well as alterations of its quality, thus impairing the nutritive value of the milk $[1 ; 2]$. It has been reported that fertility disorders and even systemic diseases can also result from mastitis $[3 ; 4 ; 2]$.

One important aspect of studies on dairy production is the modeling of the milk yield and quality $[5 ; 6$; $7 ; 8]$. Lactation curve is a graphical representation of milk production of an animal throughout a defined period [9]. It provides valuable information on the pattern of milk production during lactation, therefore, can be used in feeding and management decision support system which help optimize dairy herd productivity and /or determine the efficiency of dairy operations in relation to their physical inputs. The fitness ofthree models, Gamma, Modified Gamma and Inverse Polynomial functions to predict lactation curve of Bunaji dairy cattle have been tested, of which Gamma Function was considered most suitable for Friesian x Bunaji cows [10]. The aim of this study was to determine the prevalence of clinical mastitis and the suitability of Gamma function in predicting milk yield of mastitic and non-mastitic Friesian x Bunaji dairy cows.

\subsection{Study area}

\section{Materials And Method}

Data analyzed consisted milk yield records of Friesian x Bunaji cows kept in the Dairy Research Programme of the National Animal Production Research Institute (NAPRI) Shika, Zaria Nigeria. Shika is geographically situated on latitude $11^{\circ} 12^{\prime} 42^{\prime \prime} \mathrm{N}$ of the equator and longitude $7^{\circ} 33^{\prime} 14^{\prime \prime} \mathrm{E}$ at an altitude of $650 \mathrm{~m}$ above sea level [11]. Shika has an average annual rainfall of $1100 \mathrm{~mm}$ usually lasting from May to October; peak rainfall is recorded between July and September. Shika has a mean relative humidity of $72 \%$ while the hamarttanseason lasts from November to February with mean daily temperatures ranging from $15-36{ }^{\circ} \mathrm{C}$ and mean relative humidity of between $20-37 \%$. [11].

\subsection{Study Design and Procedure}

This was a cross-sectional study which used data from Dairy Research Programme of the National Animal Production Research Institute (NAPRI) to determine the prevalence of clinical mastitis in different parities and stages of lactation of Friesian x Bunaji dairy cows. Calculation was done using the formulas of Wolfovaet al. [12]. Lactation curve pattern of mastitic and non-mastitic Friesian x Bunaji dairy cows was designed using the Incomplete Gamma Function as described by Wood [13]. 


\subsection{Animal management}

The cows are housed in free stall barn and fed concentrate during milking, this is supplemented with hay (Digitaria) after milking/they will go grazing. They are hand-milked twice daily (morning and evening). The milking palour and utensils used for milking are cleaned with warm water and detergent after milking.

\subsection{Data Collection}

Data analyzed consisted 56.636 daily milk yield (DMY) and 446 lactations from 155 cows kept from January 2000 to April 2015 in the Dairy Research Programme, while cases of clinical mastitis (CM) were obtained from treatment records of the Animal Health Unit, of the National Animal Production and Research Institute, Shika-Zaria. The DMY was organized into mastitic and non-mastitic lactation: defined as lactation with or without the occurrence of clinical mastitis respectively. Furthermore the lactations were classified into parity: $1^{\text {st }}, 2^{\text {nd }}$ and $3^{\text {rd }}$. The amount of milk yield within 24 hours of a particular day was classified as test day milk yield. The mastitis data $(\mathrm{n}=180)$ considered were only clinical mastitis cases detected either by veterinary clinicians or the milkers at milking time, usually based on the presence of clots in the milk, swollen or hard udder. Clinical mastitis cases were treated with antibiotics, usually administered systemically. Based on date of onset of mastitis, cases were grouped as early (if they occur in the first 100 days in milk "DIM"), mid (101-200 DIM) or late (201-350 DIM)) stage of lactation.

\subsection{Data analysis}

\subsubsection{Determination of prevalence of Clinical Mastitis}

The following parameters were determined with the following formulas;

1: Lactation prevalence of clinical mastitis $(\mathrm{CM})$ for lactation $\mathrm{i}(\mathrm{i}=1,2$ or 3$)=$

Number of Cows with CM in lactation $\mathrm{i}$

Total number of Cows at risk in lactation $\mathrm{i}$

2: Mean number of $\mathrm{CM}$ cases per cow and lactation in lactation $\mathrm{i}=$

Total number of $\mathrm{CM}$ cases in Lactation $\mathrm{i}$

Total number of Cows at risk in lactation $\mathrm{i}$

3: Relative frequency of recurrence of $\mathrm{CM}$ in lactation $\mathrm{i}=$

Number of Cows treated more than once in lactation $\mathrm{i}$

Number of cows treated at least once in lactation $i$

4: prevalence of cows with CM in $\mathrm{k}$ days in milk (DIM) of lactation $\mathrm{i}=$

Numbers of Cows with CM in k DIM of lactation $\mathrm{i}$

Total numbers of Cows at risk in $\mathrm{k}$ DIM of lactation $\mathrm{i}$

5: prevalence of CM between year 2000 and $2014=$

Number of Cows with CM between 2000 and $2014 \times 100$

Number of Cows in the herd between 2000 and 2014

6: Prevalence of CM cases per cow-year at risk for lactation $1=$

Number of CM cases in lactation 1

Number of cow-day in lactation-

total number of days a cow was ill in lactation 1

\subsubsection{Lactation Curve}

Weekly test-day averages from day 7 to 305 days of lactation were considered. A minimum of 29 and maximum of 44 weekly test day averages were determined. Incomplete gamma function [13] was used to design a pattern of curve for the lactation test-day intervals. The equation used is as follows:

$$
\begin{aligned}
& Y_{t}=a t^{b} e^{-c t} \\
& \text { Where: } Y_{t}=\text { average daily milk yield in the } t^{\text {th }} \text { week, } \\
& a=\text { initial milk yield after calving, } \\
& b=\text { the ascending slope parameter up to the peak yield, } \\
& \mathrm{c}=\text { the descending slope parameter after peak yield. }
\end{aligned}
$$

Peak milk yield $(\mathrm{kg})$, time of peak milk yield (weeks) and the persistency were determined using Wood's formulas: $\mathrm{a}(\mathrm{b} / \mathrm{c})^{\mathrm{b}} \mathrm{e}^{-\mathrm{b}}, \mathrm{b} / \mathrm{c}$ and $-(\mathrm{b}+1) \ln (\mathrm{c})$ respectively [14]. The model parameters were estimated by Non-linear Least Squares Procedure using Guass Newton's Method of SAS Version 9.0 [15]. 
The lactation curve model was analyzed using Non- linear models in SAS 9.0 [15] to determine the suitability of the parameters of the Wood model ( $\mathrm{a}, \mathrm{b}$ and $\mathrm{c}$ ) in predicting the values of milk yield.

\section{Results And Discussion}

The lactation prevalence of clinical mastitis (PCM), mean number of clinical mastitis cases per cow (MCMPC) and relative frequency of recurrence of clinical mastitis (RFRCM) were found to increase with increase in parity (Table 1). The prevalence of clinical mastitis (CM) per cow-year at risk increased with parity ranging from 0.54 to 0.76 (average:0.66), (Table 1). Hand milking of cows often results in incomplete draining of the milk and provides conducive environment for mastitis causing pathogens to proliferate and cause damage to the mammary tissue and keratin layer. This could be the reason for increasing prevalence of CM with increasing parity, as it can result in reduced innate immunity of the cow because the udder tissue (mammary epithelia cells) is part of the innate host defense mechanism. Thus the observed high increases in prevalence of clinical mastitis among multiparous cows could be attributed to this reduction in the innate immunity due to reccuring infections. It could then be said that primiparous cows possibly have more intact mammary epithelia cells compared to multiparous cows, hence the lower incidence of clinical mastitis in primiparous cows. [16], also observed and reported that risk of clinical mastitis (CM) increased with increasing parity. Increase in the incidence of clinical mastitis per cow-year at risk with increasing parity have also been reported to range from 0.68 to 1.27 (12) while. Fourichon[17] got an average incidence of 0.44 , range of 0.03 to 1.38 .

Table 2 shows the prevalence of $\mathrm{CM}$ in different lactation periods of parities 1,2 and $\geq 3$. Prevalence of $\mathrm{CM}$ was highest in the early lactation period of parity $1 \mathrm{cow}$, and from the late lactation period in parities 2 and 3. High milk yielding cows remained longer in milk, reaching up to 305 days, compared to the low milk producers. The long days in milk by the high yielding cows could be the reason for the high prevalence of CM in the late lactation period in parity 2 and 3 cows, as, It is highly probable that the keratin layer in the udder could become less protective with prolonged milking therefore rendering the udder more susceptible toreinfection, possibly from a previous infection. The observed high prevalence of CM during early lactation periods in parity 1 could be attributed to new intra-mammary infections due to increase oxidative stress and reduced antioxidant defense mechanism post-partum as described by Sharma et al. [18]. The prevalence of CM in early lactation period was highest among parity 3 cows than in parity1 and 2. However, this differs from the reports of Maedeet al. [19] who found the occurrence of CM in early lactation period to be higher in parity 1 than parity 2 and $\geq 3$. This could be attributed to increased compromised integrity of the mammary epithelia cell and streak canal from the hand milking process or previous infection that can result in higher new intramammary infection during the dry period

Wood's parameters ( $\mathrm{a}, \mathrm{b}$ and $\mathrm{c}$ ) in the Wood's equation for mastitic and non-mastitic cows of parity 1 to 3 are shown in Table 3 . There was an increase in initial milk yield (a) with increasing parity from parity 1 to 3 for non-mastitic and mastitic cows. Mastitic cows in parities 2-3 had higher a-value than non-mastitic cows. The a-value for parity 1 was higher in non-mastitic than the mastitic cow.

Predicted peak milk yield (Ppmy) by Wood model was lower than the actual peak milk yield (Apmy) (Table 4). There was an increase in Ppmy with increasing parity for both mastitic and non-mastitic cow. Ppmy was higher in mastitic cows than non-mastitic cows of parity 2-3, parity 1 had a lower Ppmy in mastitc compared to non-mastitic cows. Suresh et al. [20] observed an increase in initial and peak milk yield with increasing parity. He had highest predicted and actual peak milk yields for mastitic and non-mastitickaran fries (a new breed of cow in India which is a cross between the Holstein Friesians and the Tharparkar breed) cows at parity 4. The high a-value and Ppmy in mastitic than non-mastitic cows seems to confirm the observationthat incidence of $\mathrm{CM}$ is associated with the milk production potential of a cow [21;22].

The observed higher lactation persistency in non-mastitic cows than the mastitic cows could be indication that non-mastitic cows retain peak yield longer than the mastitic cows, despite the higher milk yield of the mastic cows. Coefficient of determination was high for both mastitic and non-mastitic lactation indicating that Wood's model is a good predictor of milk yield in both mastitic and non-mastitic Friesian x Bunaji cows.

The lactation curves in figures 1 to 3 are the graphic comparison of the actual and predicted (Wood's model) values of average daily milk yield for 44 weeks lactation for mastitic and non-mastitic Friesian x Bunaji dairy cows of parities 1-3.

Table 1: Incidence of Clinical mastitis among Friesian $x$ Bunaji cows in different parities.

\begin{tabular}{|l|l|l|l|l|}
\hline Parity & PCM & MCMPC & RFRCM & ICMR \\
\hline 1 & 0.304 & 0.357 & 0.200 & 0.542 \\
\hline 2 & 0.322 & 0.441 & 0.211 & 0.683 \\
\hline 3 & 0.429 & 0.536 & 0.222 & 0.762 \\
\hline
\end{tabular}

Key: $\mathrm{PCM}=$ lactation prevalence of clinical mastitis, MCMPC = mean number of clinical mastitis per cow, RFRCM = relative frequency of recurrence of clinical mastitis and ICMR $=$ incidence of clinical mastitis per cow-year at risk. 
TABLE 2: Prevalence of Clinical mastitis in different lactation periods of Friesian and Bunaji crossbred dairy cows.

\begin{tabular}{|l|l|l|l|l|}
\hline Parity & \multicolumn{4}{|c|}{ DIM (Days) } \\
\hline & $\leq 100$ & $101-200$ & $201-300$ & $301-350$ \\
\hline 1 & $0.130(15 / 115)$ & $0.122(14 / 115)$ & $0.100(8 / 80)$ & $0.038(1 / 26)$ \\
\hline 2 & $0.119(7 / 59)$ & $0.102(6 / 59)$ & $0.250(11 / 44)$ & 0.000 \\
\hline 3 & $0.202(17 / 84)$ & $0.155(13 / 84)$ & $0.203(12 / 59)$ & 0.000 \\
\hline
\end{tabular}

Key: PCM = lactation prevalence of clinical mastitis, DIM = days in milk, 0-100 days in milk= early lactation period, 101-200 days in milk= mid lactation period and 201-350 days in milk= late lactation period.

TABLE 3: Wood's parameters ( $a, b$ and $c$ ) for mastitic and non-mastitic Friesian $x$ Bunaji dairy cows of different parities

\begin{tabular}{|c|c|c|c|c|c|c|}
\hline \multirow[t]{3}{*}{ Wood's values } & \multicolumn{6}{|l|}{ Parity } \\
\hline & \multicolumn{2}{|l|}{1} & \multicolumn{2}{|l|}{2} & \multicolumn{2}{|l|}{3} \\
\hline & Mastric & Non-Mastitic & Mastitic & Non-mastitic & Mastitic & Non-mastitic \\
\hline $\mathrm{a}$ & $5.59 \pm 0.289$ & $6.15 \pm 0.340$ & $6.89 \pm 0.409$ & $6.39 \pm 0.235$ & $7.83 \pm 0.380$ & $7.49 \pm 0.526$ \\
\hline $\mathrm{b}$ & $0.146 \pm 0.035$ & $0.1 \pm 0.024$ & $0.09 \pm 0.041$ & $0.198 \pm 0.036$ & $0.132 \pm 0.034$ & $0.13 \pm 0.047$ \\
\hline $\mathrm{c}$ & $0.02 \pm 0.003$ & $0.01 \pm 0.002$ & $0.02 \pm 0.003$ & $0.03 \pm 0.003$ & $0.03 \pm 0.003$ & $0.03 \pm 0.004$ \\
\hline
\end{tabular}

Key: $\mathrm{a}=$ represents the initial milk yield of the cow, $\mathrm{b}=$ the rate of increase to peak and $\mathrm{c}=$ the rate of decline after peak yield.

TABLE4: Peak milk yield and week of peak yield for mastitic and non-mastitic Friesian x Bunaji dairy cows of different parities

\begin{tabular}{|c|c|c|c|c|c|c|}
\hline Parameter & \multicolumn{6}{|l|}{ Parity } \\
\hline & \multicolumn{2}{|l|}{1} & \multicolumn{2}{|l|}{2} & \multicolumn{2}{|l|}{3} \\
\hline Conditions & Mastitic & Non-mastitic & Mastitic & Non-mastitic & Mastitic & Non-mastitic \\
\hline Predicted pmy & 6.35 & 7.07 & 7.18 & 7.57 & 8.44 & 8.15 \\
\hline Actual pmy & 6.67 & 7.31 & 7.51 & 7.66 & 8.85 & 8.60 \\
\hline Week of pmy & 6 & 5 & 8 & 5 & 4 & 6 \\
\hline Persistency & 4.357 & 4.760 & 4.206 & 4.392 & 4.075 & 4.164 \\
\hline $\begin{array}{l}\text { Coefficient } \\
\text { determination }\left(\mathrm{R}^{2}\right)\end{array}$ & 0.957 & 0.947 & 0.986 & 0.930 & 0.978 & 0.975 \\
\hline
\end{tabular}

pmy = peak milk yield

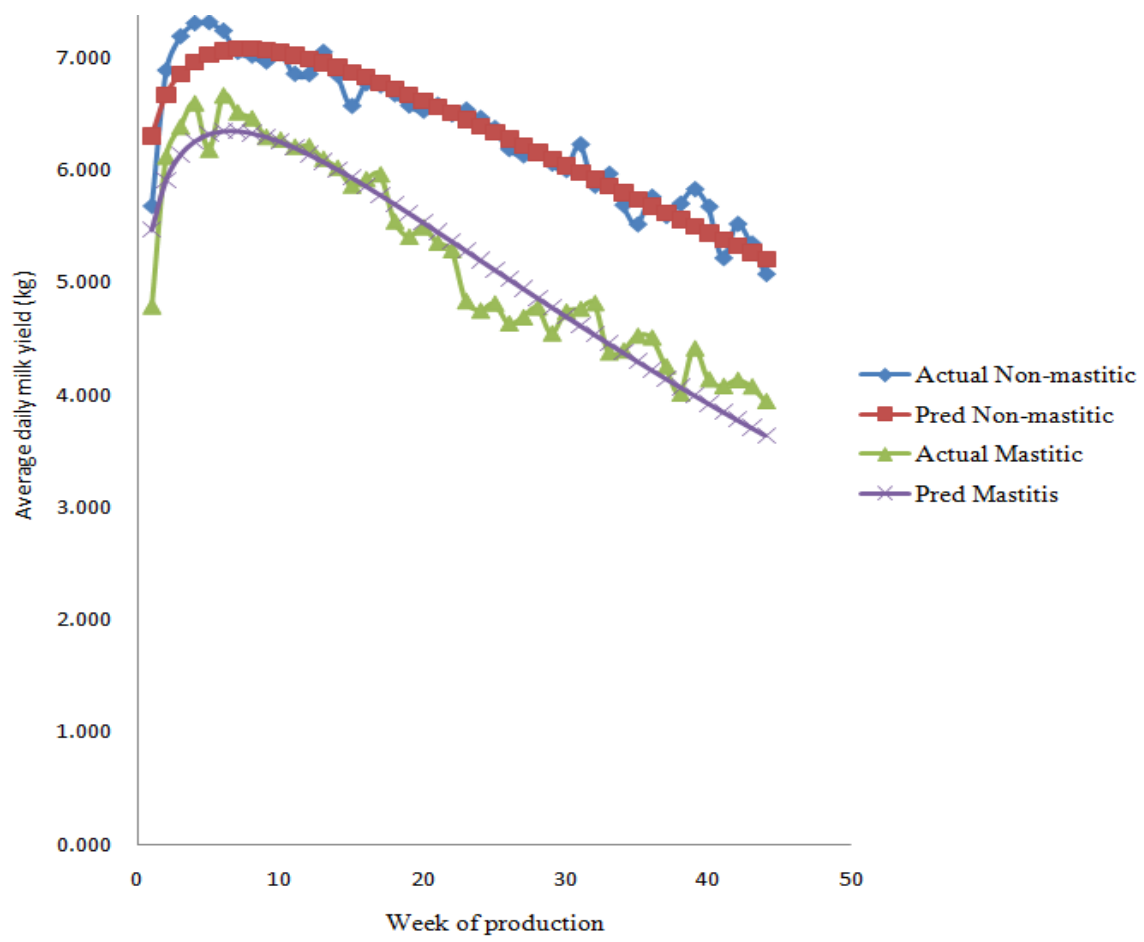

Fig 1: Parity 1 Lactation curve for Actual and predicted average daily milk yield of mastitic and non-mastitic Friesian x Bunaji dairy cows.

Key: pred $=$ predicted 


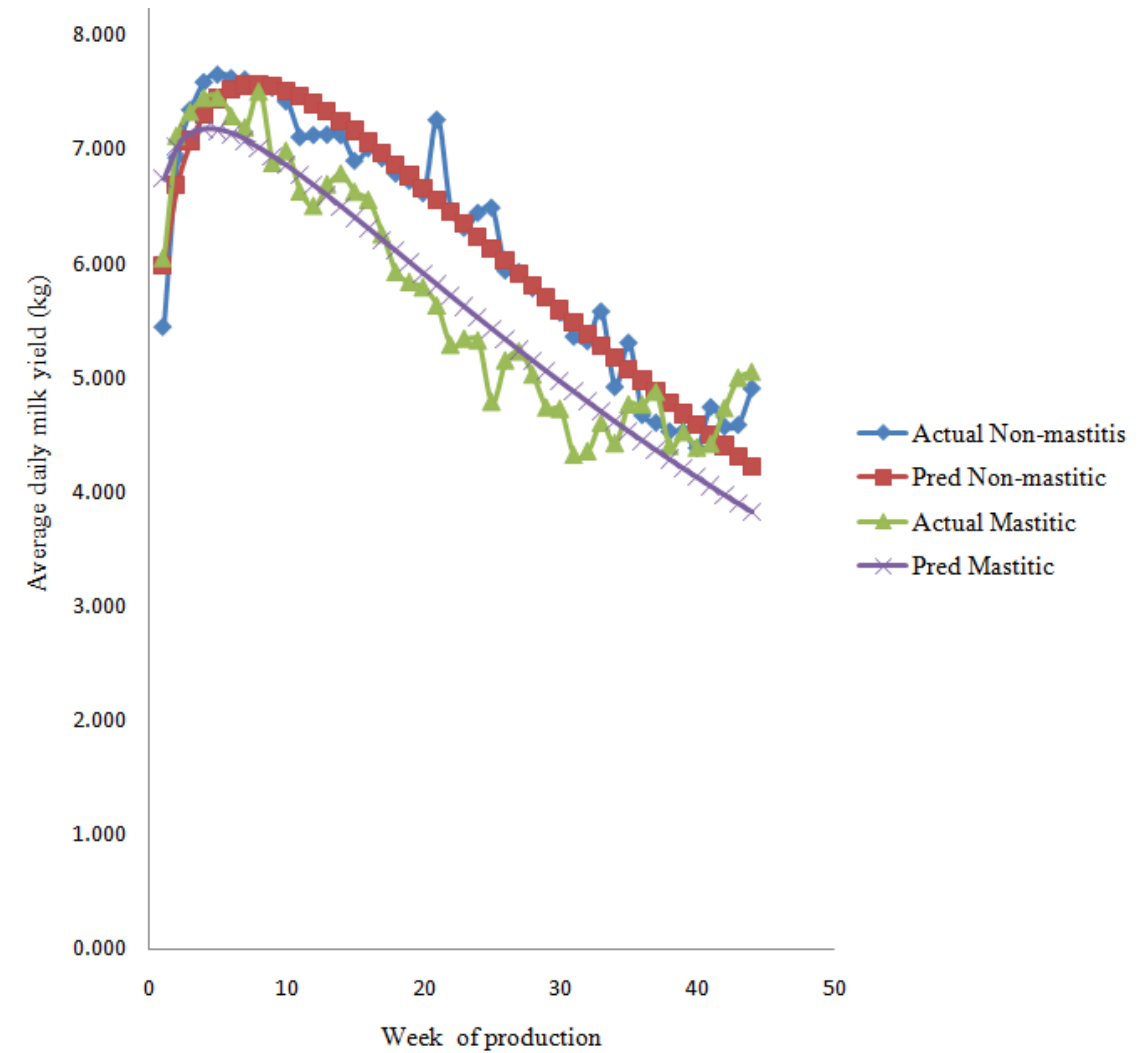

Fig 2: Parity 2 Lactation curve for Actual and predicted average daily milk yield of mastitic and non-mastitic Friesian x Bunaji dairy cows

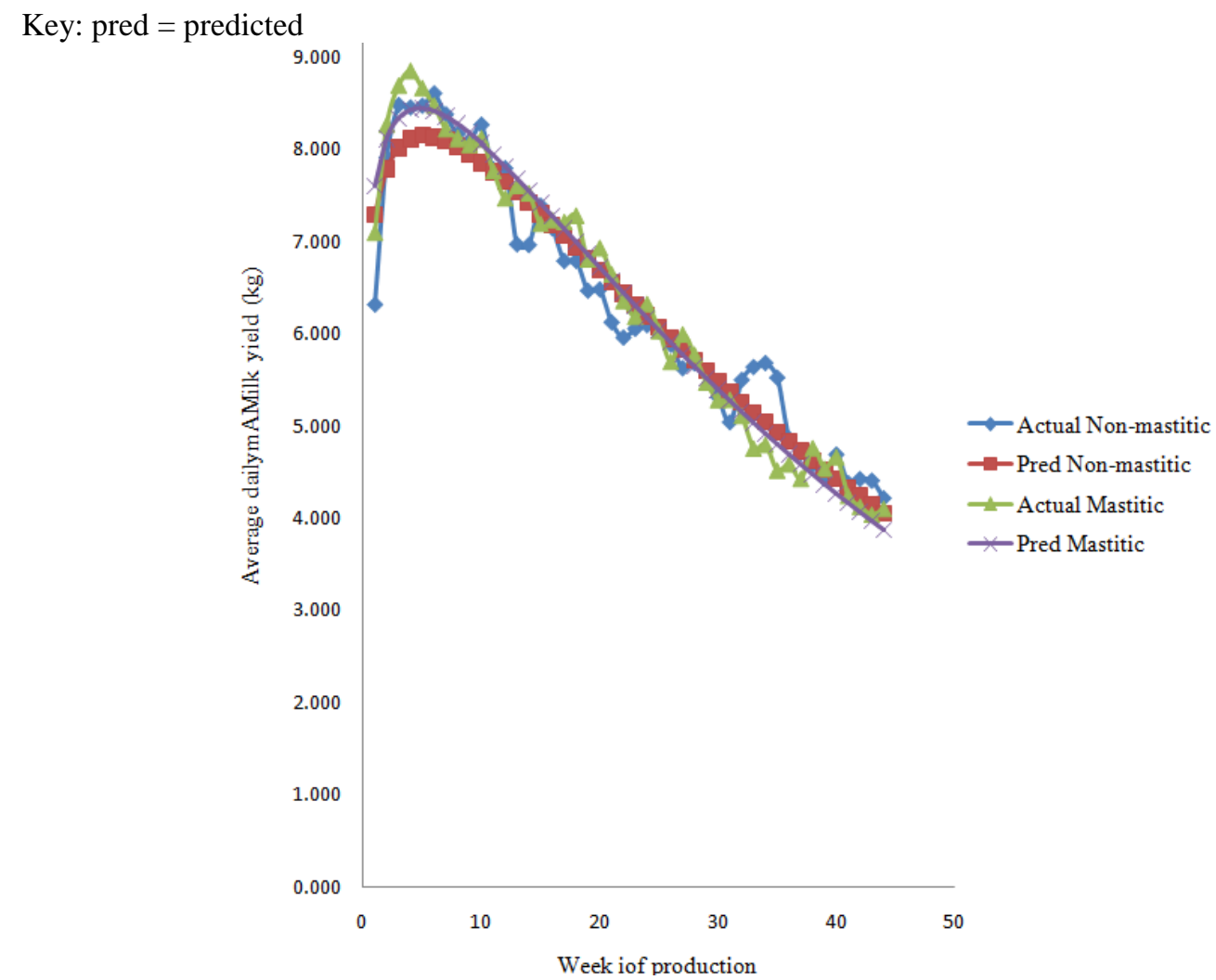

Fig 3: Parity 3 Lactation curve for Actual and predicted average daily milk yield of mastitic and non-mastitic Key: pred $=$ predicted Friesian and Bunaji dairy cows 


\section{Conclusion}

Lactation prevalence of clinical mastitis was averagely 0.35 and the prevalence of clinical mastitis per cow year at risk was averagely 0.66 . Week of peak milk yield ranged from 5-6 weeks for non-mastitic Friesian $\mathrm{x}$ Bunaji cows and 4-8 weeks for mastitic Friesian $\mathrm{x}$ bunaji cows. Wood's model was able to predict accurately peak milk yields of parity 1, 2 and 3 for mastitic and non-mastitic Friesian x Bunaji cows, the coefficient of determination obtained were high, above 0.90. though, newer models are still emerging which could be compared to Woods model to determine if they are better in predicting milk yield of Friesian x Bunaji cows.

\section{Acknowledgement}

Our gratitude goes to Macarthur Foundation for sponsoring this research. We are also grateful to the Executive Director of the National Animal Production Research Institute (NAPRI) for permitting us to use these Data and to the Staff of Dairy Research Programme of NAPRI for making the Data available to us. To the Staff of Veterinary Public Health and Preventive Medicine, thanks for all your contributions.

\section{References}

[1]. T. Halasa, K. Huijps, O. Osteras, H. Hogeveen. Economic effects of bovine mastitis and mastitis management: A review. Veterinary Quarterly.29, 2007, 18-31.

[2]. M.M. Awale, G.B. Dudhatra, K. Avinash, B.N. Chauhan, D.R. Kamani, C.M. Modi, H.B. Patel, R. O’Kennedy. Bovine mastitis: a threat to economy. Open Access Scientific Reports 1, 2012, 295. doi:10.4172/scientific reports. 295.

[3]. E. Malinowski, and Z. Gajewski, Mastitis and fertility disorders in cows.Polish Journal of Veterinary Sciences.13,2010, 555-560.

[4]. C. Le Marechal, R. Thiery, E. Vautor, Y. Le Loir. Mastitis impact on technological properties of milk and quality of milk products - a review.Dairy Science and Technology.91, 2011, 247-282.

[5]. D.E. Beever, A.J. Rook, J. France, M.S. Dhanoa, and M. Gill, M. A review of empirical and mechanistic models of lactation performance by the dairy cow. Livestock Production Science.29,1991, 115-130.

[6]. R.E. Kamidi, A parametric measure of lactation persistency in dairy cattle. Livestock Production Science 96, 2005, 141-148

[7]. S.V. Morant, and A. Gnanasakthy, A new approach to the mathematical formulation of lactation curves.Animal Production.49, 1989, 151- 162 .

[8]. B.E. Mostert, H.E. Theron, F.H.J. Kanfer, Derivation of standard lactation curves for South African dairy cows. South African Journal of Animal Science.33, 2003, 70- 77.

[9]. M.C.Yadav, B.C. Katpatal, and S.N. Kavshik, Components of gamma type function of a lactation curve, and factors affecting them in Hariana and its Friesian crosses. Indian Journal of Animal Science.49(9), 1977, 502-505.

[10]. S. A. S. Olorunju, Evaluation of models for lactation curves for Bunaji, Friesian and Friesian-Bunaji crossbred cows in Nigeria. Doctorate diss,.Ahmadu Bello University, Zaria, Nigeria. 1980.

[11]. Ovimaps, Ovi location map; Ovi earth imagery date: July $7^{\text {th }}, 2014$.

[12]. M.Wolfova, M. Stipkova, and J. Wolf, Incidence and Economics of Clinical Mastitis in Five Holstein Herds in the Czech Republic. Preventive Veterinary Medicine.77(1- 2), 2006, 48-64.

[13]. P.D.P. Wood, Algebraic model of the lactation curve in cattle. Nature.216, 165. 1967.

[14]. B. Rekik, A. Ben Gara, M. Ben Hamouda, H. Hammami, Fitting lactation curves of dairy cattle in different types of herds in Tunisia. Livestock Production Science.83, 2003, 309-315.

[15]. SAS Institute, SAS/STAT User's Guide: Statistics. SAS Institute Incorperated, Cary, North Carolina. 1999.

[16]. W. Steeneveld, H. Hogeveen, H.W. Barkema, J. van den Broek, and R.B.M. Huirne, The Influence of Cow Factors on the Incidence of Clinical Mastitis in Dairy Cows. Journal of Dairy Science.91(4), 2008, 1391-1402.

[17]. C. Fourichon, F. Beaudeau, N. Bareille, and H. Seegers, Incidence of health disorders in dairy farming systems in Western France. Livestock Production Science.68, 2001, 157-170.

[18]. N. Sharma, N.K. Singh, O.P. Singh, V. Pandey, P.K. Verma, Oxidative stress and antioxidant status during transition period in dairy cows. Asian-Australasin Journal of Animal Science.24, 2011, 479-484.

[19]. M. Maede, M. Abdolah, G. Mohsen, and T. Amin, Relationship between season, lactation number and incidence of clinical mastitis in different stages of lactation in a Holstein dairy farm. Veterinary Research Forum.5 (1), 2014, 13 - 19.

[20]. J. Suresh, R.K. Mehla, S. Mahendra, and A.K.Roy, Lactation Curve Pattern and Prediction of Milk Production Performance in Crossbred Cows.Journal of Veterinary Medicine.2014, 6 pages.doi:10. Article ID 814768, 1155/2014/814768

[21]. Y.T. Gröhn, D.J. Wilson, R.N. Gonzalez, J.A. Hertl, H. Schulte, G. Bennett, and Y.H. Schukken, Effect of Pathogen-Specific Clinical Mastitis on Milk Yield in Dairy Cows. Journal of Dairy Science.87(10), 2004, 3358-3374.

[22]. D.J. Wilson, R.N. Gonzalez, J.A. Hertl, H.F. Schulte, G.J. Bennett, Y.H. Schukken, and Y.T. Gröhn, Effect of Clinical Mastitis on the Lactation Curve: A Mixed Model Estimation Using Daily Milk Weights. Journal of Dairy Science.87(7), $2004,2073-2084$. 